\title{
Fertilizer Effects on Above- and Below- ground Biomass of Four Species
}

\author{
JERRY L. HOLECHEK
}

\begin{abstract}
Research was conducted in a greenhouse at Bozeman, Montana, and on coal mine spoils at Colstrip, Montana, in 1975 to determine production characteristics of four species when nitrogen and phosphorus fertilizer was applied at a low rate and when not applied. Aboveground biomass, belowground biomass, and the root to shoot ratio of fairway crested wheatgrass (Agropyron cristatum), critana thickspike wheatgrass (Agropyron dasystachyum), and fourwing saltbush (Atriplex canescens) were increased by fertilizer application. Root depths of crested and thickspike wheatgrass were increased by fertilizer application. Ranger alfalfa (Medicago sativa) responded differently to fertilizer application in the greenhouse and field experiments. Crested wheatgrass had a higher root to shoot ratio than the other three species when fertilizer was not applied. This may explain why this species has been successful in the Northern Great Plains.
\end{abstract}

During the research the author was graduate assistant, Department of Animal and Range Sciences, Montana State University, Bozeman. He is currently assistant professor of range ecology, Department of Animal and Range Sciences, New Mexico State University, Las Cruces 88003 .

This article is published as Journal Series No. 869, Montana Agricultural Experiment Station, Bozeman, Montana.

The research was funded by the U.S. Forest Service Surface Environment and Mining (SEAM) Program and was part of Cooperative Agreement No. 16, (USC 581; $581 a-581 i)$.

JOURNAL OF RANGE MANAGEMENT 35(1), January 1982
The application of nitrogen and phosphorus fertilizer has had variable effects on plant establishment and productivity in rangeland revegetation studies. Most research has shown that nitrogen and phosphorus fertilizer did not increase seedling emergence or survival (Hull 1963, Cook 1965, Bryan and Murphy 1968, Farmer et al. 1974, Holechek 1979). Generally, nitrogen and phosphorus fertilizer application has increased the vigor of cool-season grasses (Black 1968, Wight and Black 1972, Mason and Miltimore 1972, Ryerson et al. 1974). Close correlations have been made between the increased yield of cool-season grasses resulting from nitrogen and phosphorus fertilization and increased depth and quantity of roots in the Northern Great Plains (Van Dyne 196, Black 1968, Mason and Miltimore 1972). Increasing these root parameters allows better soil moisture extraction. Nitrogen fertilization generally does not benefit legumes because nitrogen fixing bacteria are associated with these plants (Brady 1974). However, phosphorus application has, in most cases, increased legume production (Brouse and Burzlaff 1968, Martin et al. 1965, Brady 1974). Generally, nitrogen and phosphorus fertilizer has increased shrub production (Gibbens and Pieper 1962, Bayoumi and Smith 1966, Anderson et al. 1974, George and Powell 1977, Barrett 1979).

The objectives of this research were to determine the effects of nitrogen and phosphorus fertilizer application on root to shoot 
ratios and root depths of four species planted in a greenhouse at Bozeman, Montana, and on strip mine spoils at Colstrip, Montana. The four species used in the investigation included critana thickspike wheatgrass (Agropyron dasystachyum), fairway crested wheatgrass (Agropyron cristatum), ranger alfalfa (Medicago sativa), and fourwing saltbush (Atriplex canescens).

\section{Methods}

In late winter of 1975 , a representative sample of surface topsoil was taken from strip mine spoils at Colstrip, Montana, and transported to a greenhouse owned by Montana State University at Bozeman. Approximately $88 \mathrm{~kg}$ of soil materials were weighed and placed in each of 24 rectangular frames on greenhouse benches. Fourwing saltbush, critana thickspike wheatgrass, ranger alfalfa, and fairway crested wheatgrass were randomly assigned to the experimental units. This resulted in six replications of each species in a completely randomized design. Experimental units were broadcast seeded on the basis of pure live seed per square meter on March 22. Seeds were incorporated into the spoils material by hand cultipacking. All seeds in the study had been recently tested for germination. Fourwing saltbush seed was dewinged. Ranger alfalfa seed was inoculated with nitrogen-fixing bacteria. Fairway crested wheatgrass, critana thickspike wheatgrass, and ranger alfalfa were broadcast seeded at 538 pure live seeds $/ \mathrm{m}^{2}$. This seeding rate was used to compensate for the uneven depth of broadcast seeding (Vallentine 1971). Fourwing saltbush was seeded at a reduced rate ( 108 pure live seeds $/ \mathrm{m}^{2}$ ) to lower intraspecific competition. Water and temperature were controlled so that average conditions at Colst rip for each month were approximated. Nitrogen and phosphorus fertilizer was randomly applied to one half the experimental units seeded to each mixture immediately after germination. The rates of application were $37 \mathrm{~kg} / \mathrm{ha}$ of nitrogen and $94 \mathrm{~kg} / \mathrm{ha}$ of phosphorus.

Experimental units, $9 \times 10 \mathrm{~m}$, were established on strip mine spoils at Colstrip that had been previously ripped and topsoiled during the same period. The study was set up with three blocks of eight experimental units. The four species were assigned randomly to each block. Seeding was accomplished by broadcasting and then cultipacking on April 4. The same seeding rates were used as in the greenhouse study. Nitrogen and phosphorus fertilizer was applied at the same rate used in the greenhouse to one half the experimental units in each block after germination. Data concerning the emergence and survival of the four species in the field and greenhouse experiments are given by Holechek (1980). The mean annual precipitation for the Colstrip area is approximately $40 \mathrm{~cm}$ (Sindelar et al. 1973). Precipitation during the 1975 growing season was $107 \%$ of the average. Data concerning the physical and chemical characteristics of the soil material on the study area are given by Holechek (1976).

Aboveground biomass in the greenhouse was evaluated by clip- ping each experimental unit on July 2, 1975. Belowground biomass was evaluated immediately after clipping by placing soil material in screens and flushing with water.

Aboveground biomass was clipped on August 19, 1975, in the field experiment. The methods used in collecting belowground biomass were modified slightly from those used by Bartos and Sims (1974). Belowground biomass samples were collected on each experiment unit with a portable gas operated soil sampler on August 26, 1975. Weeds were pulled up a round the area of sample collection so belowground biomass would represent the seeded species.

In order to evaluate root elongation of the four species in the greenhouse, each species was planted in boxes with glass sides. Fertilizer was applied to one half the boxes at the same rate used to evaluate biomass. Root boxes were replicated for thickspike and crested wheatgrass but not for ranger alfalfa and fourwing saltbush. On June 28 rooting depth was evaluated in the greenhouse. Rooting depth in the field experiment was evaluated on August 27, 1975 , by excavating 15 plants from each experimental unit.

Differences in aboveground biomass, belowground biomass, root to shoot ratios, and rooting depths were analyzed by analysis of variance using the procedures of Steel and Torrie (1960). Newman-Keuls tests for significance was used to rank treatment means.

\section{Results}

Aboveground biomass, belowground biomass, and root to shoot ratios of the four species in the greenhouse and field experiments are given in Table 1 . Only results statistically significant $(P<.05)$ will be discussed. Fertilizer application significantly increased aboveground biomass of all four species in the greenhouse experiment. In the field, fertilizer application significantly increased the aboveground biomass of crested and thickspike wheatgrass. Belowground biomass was significantly increased by fertilizer application for all species in the greenhouse. In the field, fertilizer application significantly increased the belowground biomass of crested wheatgrass, thickspike wheatgrass, and fourwing saltbush. Fertilizer application significantly increased the root to shoot ratios of crested wheatgrass, thickspike wheatgrass, and fourwing saltbush in both experiments.

Rooting depths of the four species in both experiments are given in Table 2. Crested and thickspike wheatgrass had significantly $(P<.05)$ greater rooting depths on fertilized compared to unfertilized experimental units in both experiments. Fourwing saltbush had a greater rooting depth than the other three species in the greenhouse. However, statistical comparisons were not made because of lack of replication. In the field fourwing saltbush had a significantly $(P<.05)$ greater rooting depth than the other three species.

Table 1. Aboveground hiomass, belowground biomass, and root to shoot ratios in the field and greenhouse experiments.

\begin{tabular}{|c|c|c|c|c|c|c|}
\hline \multirow[b]{2}{*}{ Greenhouse $^{1,2}$} & \multicolumn{2}{|c|}{$\begin{array}{c}\text { Aboveground biomass } \\
(\mathrm{kg} / \mathrm{ha})\end{array}$} & \multicolumn{2}{|c|}{$\begin{array}{c}\text { Belowground }{ }^{3} \text { biomass } \\
(\mathrm{kg} / \mathrm{ha})\end{array}$} & \multicolumn{2}{|c|}{ Root/Shoot } \\
\hline & Fertilized & Unfertilized & Fertilized & Unfertilized & Fertilized & Unfertilized \\
\hline $\begin{array}{l}\text { Agropyron dasystachyum } \\
\text { Agropyron cristatum } \\
\text { Medicago sativa } \\
\text { Atriplex canescens }\end{array}$ & $\begin{array}{r}1074^{a} \\
1151^{a} \\
569^{b} \\
535^{b}\end{array}$ & $\begin{array}{l}316^{a} \\
315^{\mathrm{a}} \\
327^{a} \\
280^{\mathrm{a}}\end{array}$ & $\begin{array}{r}2054^{b} \\
2178^{a} \\
683^{c} \\
744^{c}\end{array}$ & $\begin{array}{l}327^{b} \\
420^{a} \\
325^{b} \\
204^{c}\end{array}$ & $\begin{array}{l}1.91^{\mathrm{a}} \\
1.89^{\mathrm{a}} \\
1.20^{\mathrm{b}} \\
1.39^{\mathrm{b}}\end{array}$ & $\begin{array}{l}1.03^{\mathrm{b}} \\
1.33^{\mathrm{a}} \\
0.99^{\mathrm{c}} \\
0.73^{\mathrm{c}}\end{array}$ \\
\hline \multicolumn{7}{|l|}{ Field $^{1,2}$} \\
\hline $\begin{array}{l}\text { Agropyron dasystachyum } \\
\text { Agropyron cristatum } \\
\text { Medicago sativa } \\
\text { Atriplex canescens }\end{array}$ & $\begin{array}{r}197^{\circ} \\
118^{\mathrm{b}} \\
139^{\mathrm{b}} \\
67^{\mathrm{c}}\end{array}$ & $\begin{array}{r}91^{\mathrm{b}} \\
61^{\mathrm{c}} \\
173^{\mathrm{a}} \\
56^{\mathrm{c}}\end{array}$ & $\begin{array}{r}280^{a} \\
275^{a} \\
143^{b} \\
90^{c}\end{array}$ & $\begin{array}{r}96^{b} \\
110^{b} \\
210^{z} \\
40^{c}\end{array}$ & $\begin{array}{l}1.42^{\mathrm{b}} \\
2.33^{\mathrm{a}} \\
1.03^{\mathrm{c}} \\
1.34^{\mathrm{b}}\end{array}$ & $\begin{array}{l}1.05^{b c} \\
1.80^{a} \\
1.21^{b} \\
0.86^{c}\end{array}$ \\
\hline
\end{tabular}

IStatistical comparisons and significance are valid only within each column.

2Treatments with different letters are significantly different $(\mathcal{F}<.05)$ using Newman-Keuls Test.

${ }^{3}$ Belowground biomass is presented on an ash-free basis. 
Table 2. Root depths $(\mathrm{cm})$ of the four species in the greenhouse and field experiments.

\begin{tabular}{lccccc}
\hline \hline & \multicolumn{2}{c}{ Greenhouse } & & \multicolumn{2}{c}{ Field } \\
\cline { 2 - 3 } \cline { 5 - 6 } & Fertilized & Unfertilized & & Fertilized & Unfertilized \\
\hline Atriplex canescens & 50.6 & 45.1 & 35.3 & 31.7 \\
Medicago sativa & 43.8 & 42.9 & & 23.6 & 23.1 \\
Agropyron cristatum & 28.1 & $21.2^{3}$ & & 17.0 & $14.0^{2}$ \\
Agropyron dasystachyum & 25.8 & $19.3^{2}$ & & 17.5 & $13.5^{2}$ \\
\hline
\end{tabular}

1 Fertilized and unfertilized treatments with Atriplex canescens and Medicago sativa in the greenhouse were not compared statistically because of lack of replication.

${ }^{2}$ Fertilized and unfertilized treatments differed significantly at $P<.05$.

${ }^{3}$ Fertilized and unfertilized treatments differed significantly at $\mathbb{R}<.01$.

\section{Discussion}

Data from this research showed that nitrogen and phosphorus fertilizer influenced individual species much differently. Differences between the greenhouse and field studies demonstrate that weather conditions also play a big role in plant response to fertilizer application. Environmental conditions in the greenhouse were much different than those in the field. This same kind of difference exists in environmental conditions between years. For this reason, data from any $l$ year of study involving fertilizer application must be interpreted with considerable caution. This study al so shows the danger of applying greenhouse data to conditions existing in the field.

Crested and thickspike wheatgrass had greater aboveground biomass, belowground biomass, root to shoot ratios, and rooting depths when fertilizer was applied in both experiments. Black (1968) reported that nitrogen and phosphorus fertilizer application increased root weight and depth of crested wheatgrass in Montana. Other studies are available showing nitrogen and phosphorus fertilizer increased the vigor of cool-season grasses by increasing root weight and length (USDA 1961, Cook 1965).

Several studies have shown that nitrogen and phosphorus fertilizer increased the vigor and aboveground production of crested wheatgrass (Eckert et al. 1961, Cook 1965, Power and Alessi 1970, Depuit and Coenenberg 1979). The results from the present study are consistent with these past findings.

Considerable data are available showing crested wheatgrass is highly adapted to the harsh climatic conditions existing on the Northern Great Plains (Reitz et al. 1936, Houston 1957, Rogler 1960, Lodge et al. 1972, Depuit and Coenenberg 1979). In this study, crested wheatgrass had a significantly higher $(P<.01)$ root to shoot ratio than the other three species when fertilizer was not applied. This may explain why crested wheatgrass can withstand periodic drought and defoliation better than many native species. A greater root biomass in relation to vegetative biomass should theoretically result in greater efficiency of soil moisture use because of a reduced transpiration rate.

The response of ranger alfalfa to nitrogen and phosphorus fertilizer application in the greenhouse and field experiments was not consistent for aboveground biomass, belowground biomass, and root to shoot ratios. Since this species was inoculated with nitrogen-fixing bacteria, its productivity was probably much less limited by nitrogen than the grasses'. In the field, competition from weeds was greater than in the greenhouse. Weed productivity was significantly $(P<.05)$ increased by fertilizer application. Ranger alfalfa may have had a competitive advantage over weeds in the field experiment when fertilizer was not applied because it was less limited by nitrogen availability. The application of phosphorus without nitrogen may increase ranger alfalfa biomass. This nutrient has been found to be more limiting to legume production than nitrogen (Brady 1974).

Fourwing saltbush aboveground biomass, belowground biomass, and root to shoot ratios were all significantly $(P<.05)$ increased by nitrogen and phosphorus fertilizer application. It appears that fertilizer application could be very effective in aiding the establishment of this species.

On fertilized and unfertilized experimental units in the field and greenhouse studies, fourwing saltbush had a greater root depth than the other three species. Research is available showing good initial and long-term establishment of fourwing saltbush on mine spoils at Colstrip (Depuit and Coenenberg 1978, Holechek 1980). Rapid root elongation may explain why plantings of this species have been successful.

\section{Conclusion}

Based on the cvidence of this research, nitrogen, and phosphorus fertilizer applied at a low rate after seedling emergence increased above-ground biomass, belowground biomass, and root to shoot ratios of fairway crested wheatgrass, critana thickspike wheatgrass, and fourwing saltbush. It appears that low application rates of nitrogen and phosphorus fertilizer may be beneficial in improving establishment of these three species on harsh areas in the Northern Great Plains where fertility is low.

\section{Literature Cited}

Anderson, B.L., R.D. Pieper, and V.W. Howard, Jr. 1974. Growth response and deer utilization of fertilized browse. J. Wildl. Manage. 38:525-530.

Barrett, Morley W. 1979. Evaluation of fertilizer on pronghorn winter range in Alberta. J. Range Manage. 32:55-60.

Bartos, D.L., and P.L. Sims. 1974. Root dynamics of a shortgrass ecosystem. J. Range Manage. 27:33-36.

Bayoumi, M.A., and A.D. Smith. 1976. Response of big game winter range vegetation to fertilization. J. Range Manage. 29:44-48.

Black, A.L. 1968. Nitrogen and phosphorous fertilization for production of crested wheatgrass and native grass in northeastern Montana. Agron. J. 60:213-216.

Brady, Nyle C. 1974. The nature and properties of soils. MacMillan Publishing Company, New York. 592 p.

Brouse, E.M., and D.F. Burzlaff. 1968. Fertilizers and legumes on subirrigated meadows. Nebraska Agr. Exp. Sta. Bull. 501. 32 p.

Bryan, G.G., and W.E. Murphy. 1968. Competition and fertilization as influences on grass seedlings. J. Range Manage. 21:98-101.

Cook, C. Wayne. 1965. Plant and livestock responses to fertilized rangelands. Utah Agr. Exp. Sta. Bull. 455.63 p

Depuit, E.J., J.G. Coenenberg, and W. Willmuth. 1978. Research on vegetation of surface mined lands. Montana Agr. Res. Sta. Res. Rep. 127, Bozeman. 165 p.

Depuit, E.J., and J.G. Coenenberg. 1979. Responses of vegetated coal strip mine spoils to variable fertilizer rates, longevity of fertilization program and season of seeding. Montana Agr. Exp. Sta. Res. Rep. 150, Bozeman. $81 \mathrm{p}$.

Eckert, Richard E., Jr., A.T. Bleak, and Joseph H. Robertson. 1961. Effect of macro and micro nutrients on the yield of crested wheatgrass. J. Range Manage. 14:149-155.

Farmer, E.E., R.W. Brown, B.A. Richardson, and P.E. Packer. 1974. Vegetation research on the Decker coal mine in southeastern Montana. USDA Forest Serv. Res. INT-162, 12 p.

Gibbens, R.P., and R.D. Pieper. 1962. The response of browse plants to fertilized elm sprouts. J. Range Manage. 30:268-281.

George, J.F., and J. Powell. 1977. Deer browsing and browse production of fertilized elm sprouts. J. Range Manage. 30:357-360.

Holechek, Jerry L. 1976. Initial effects of different species treatments and fertilizer rates on a mine spoils rehabilitation. Unpublished Masters Thesis. Montana State Univ., Bozeman. 91 p.

Holechek, Jerry L. 1979. Fertilizer effects on initial plant establishment on a mine spoils rehabilitation. Abst. of 32nd Annu. Meeting. Soc. Range Manage. $46 \mathrm{p}$.

Holechek, Jerry L. 1980. Initial establishment of four species on mine spoils. J. Range Manage. 34:76-77.

Houston, Walter R. 1957. Seeding crested wheatgrass on drought depleted ranges. J. Range Manage. 10:131-134.

Hull, A.C., Jr. 1963. Fertilization of seeded grasses on mountainous rangelands in northeastern Utah and southeastern ldaho. J. Range Manage. 16:306-310.

Lodge, Robert W., Sylvester Smoliak, and Alexander Johnston. 1972. Managing crested wheatgrass pastures. Canada Dep. Agr. Pub. 1473.55 p. 
Martin, William E., Victor V. Rendig, Arthur Haig, and Lester J. Berry. 1965. Fertilization of irrigated pasture and forage crops in California. Agr. Exp. Sta. Bull. 815. 28 p.

Mason, J.L., and J.E. Miltimore. 1972. Ten year field response of beardless wheatgrass from a single nitrogen application. J. Range Manage. 25:269272.

Power, J.F., and J. Alessi. 1970. Effects of nitrogen source and phosphorous on crested wheatgrass growth and water use. J. Range Manage. 23:175-178.

Reitz, L.P., M.A. Bell, and H.E. Tower. 1936. Crested wheatgrass in Montana: Comparisons with slender wheatgrass and bromegrass. Montana. Agr. Exp. Sta. Bull. 323. 53 p.

Rogler, G.A. 1960. Growing crested wheatgrass in the western states. USDA Leaf 469.

Ryerson, D.E., R. Roath, R. Rhode, G. Maxness, and W. Cornwell. 1974. Vegetation response to fertilization, grazing, and deferment of grassland communities in Buggy Creek State Grazing District. Montana Agr. Exp. Sta. Res. Dep. 64. 26 p.

Sindelar, B.W., R.L. Hodder, and M.E. Majerus. 1973. Surface mined land reclamation research in Montana. Research Report 40. Montana Agr. Exp. Sta. Res. Dep. 40.122 p.

Steel, R.G., and J.H. Torrie. 1960. Principles and procedures of statistics. McGraw-Hill Book Co., New York. 532 p.

USDA, Agr. Rex. Serv. 1961. Fertilized plants drink deep. Agr. Res. 9:10-11.

Vallentine, J.F. 1971. Range development and improvement. Brigham Young Univ. Press, Provo, Utah. 515 p.

Van Dyne, G.M. 1961. Range fertilization studies, Red Bluff Research Ranch, Montana Agr. Exp. Sta. Progress Rep. PR-1, 2, and 3.

Wight, J.R., and A.L. Black. 1972. Energy fixation and precipitation-use efficiency in a fertilized rangeland ecosystem of the Northern Great Plains. J. Range Manage. 25:376-380.
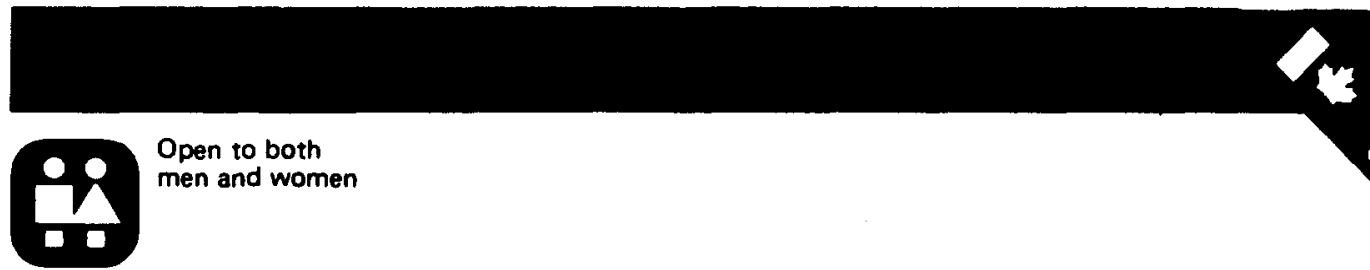

\section{Career Opportunities in Science

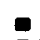 the Public Service of Canada}

Research Scientists

\section{Remuneration - $\$ 23,225$ to $\$ 50,028$ (dependent upon scientific productivity)}

If you are a forward thinking scientist with a desire to develop your career in research. the Public Service of Canada may be the place for you. The Federal Government is involved in many fields of research and the need for scientists is continuous and variable as new programs are established. To meet these needs, the Public Service Commission of

Canada (Ottawa) maintains an applicant inventory of scientists who are in terested in contributing to the research programs of the Federal Government.

You are invited to submit your résume. describing your present field of research and future ambitions. Should your expertise not be in im mediate demand your application will be retained in inventory for consideration as vacancies do occur. Salaries will be in accordance with your productivity as a scientist and are competitive with other employers. All applications will be administered in the strictest of confidence.

The fields of research within the Public Service of Canada for which there is a requirement for scientists are many. It is expected that vacancies will be available during the year for scientists with research experience in grazing management practices to increase the efficiency of production and utilization of native and cultivated forage useful to: the livestock industry.

\section{How to apply}

Interested persons are invited to send their applications and/or résumé to the following address Quoting Ref No: 81 -NCRSO-RES-1 and specifying field of scientific endeavour:

Miss J. Girling

National Capital Region Staffing Office

Public Service Commission of Canada

300 Laurier Avenue West

Ottawa, Ontario K1A $0 \mathrm{MT}$

Telephone (613) 593-5331 THERE PROBABLY IS A PLACE FOR YOU! 